\title{
sciendo
}

\section{Correlative approach to digitalization and economic growth}

\author{
Irina GEORGESCU \\ The Bucharest University of Economic Studies, Bucharest, Romania \\ irina.georgescu@csie.ase.ro \\ Ane-Mari ANDRONICEANU \\ The Bucharest University of Economic Studies, Bucharest, Romania \\ ane.androniceanu.drd@gmail.com \\ Jani KINNUNEN \\ Ábo Akademi, Turku, Finland \\ jani.kinnunen@abo.fi \\ Irina Virginia DRĂGULĂNESCU \\ University of Bucharest, Bucharest, Romania \\ irina.dragulanescu@faa.unibuc.ro
}

\begin{abstract}
It is known that the evolution of digital technologies, together with a combination of other essential generic technologies, leads to a change in the way we design, produce and market related products and services, as well as in the way how value is generated from them. Digitalization and transformation of the business process to create remarkable customer experience are absolutely necessary for any company that wants to evolve and succeed in the fast-digitizing business environment. The main objective of this research was to discover how digitalization influences economic growth. The databases used were Eurostat and World Bank. We selected 8 main research variables, which were divided into two sets to describe (i) the phenomenon of digitalization by digital skills, mobile subscriptions, enterprises with e-commerce, and (ii) the phenomenon of economic growth by real GDP growth, unit labour cost growth, resource productivity and $R \& D$ expenditure of GDP. The research methodology was centred on Canonical Correlation Analysis to reveal the connections within and between the two phenomena. The results revealed, for example: the digitalization set was able to explain $70.33 \%$ of economic growth with the correlation of 0.800; the real GDP growth is affected by the share of enterprises involved with e-commerce, unit labour costs and resource productivity are affected by highlevel digitalization seen by enterprises conducting data analysis on customers for marketing purposes; and that digital skills and $R \& D$ expenditures are positively related.
\end{abstract}

Keywords: digitalization, economic growth, canonical correlation analysis.

\section{Introduction}

Most economies in developed countries are based on innovation and technology. Technology replaces manual labour in most aspects of life and in most segments of the economy (ConnollyBarker et al., 2020). Life offline is gradually becoming impossible. Digital transformation is the process of discovering new business applications that integrate data (Bimber et al., 2012; Kinnunen and Georgescu, 2020). Digitization influences the development of the digital business.

Digital transformation requires digital business and digitization. Although each business has its own specifics, there are some elements of digital transformation that appear in each case. The main element that changes for the better is the customer experience. It has easier access to information and the final product. Then, operational agility is improved because most

DOI: 10.2478/picbe-2021-0006

(C) 2021 I. Georgescu, A.-M. Androniceanu, J. Kinnunen, I. V. Drăgulănescu, published by Sciendo. This work is licensed under the Creative Commons Attribution 4.0 License. 
intermediaries disappear. Digitization also brings transformations in terms of organizational culture and leadership. Of course, this does not mean that all companies that aim to digitize their own processes and services succeed. In fact, studies show that about $70 \%$ of digital transformation processes fail (Androniceanu et al., 2020a, Androniceanu et. al, 2020). It can be said that two aspects are essential for digitalization: resources (human, material, informational and financial) and the management of organizations/governments that aim for a digital transformation (Kljucnikov et al., 2019). Digitization is necessary and must have a real stake: to solve challenges or problems that a business faces or to serve the unaddressed needs of a category of public or stakeholder in the market.

Digitalization is a process of change, which has a major impact on people and the processes they go through. The digital transformation generates efficiency, speed, productivity, and a reduction in errors - and all these gains are reflected not only in the indicators of economic growth and performance but also in terms of competitiveness, reputation, and brand (Androniceanu et al., 2020b).

In the European economy, digitalization has a major impact (Androniceanu et al., 2019; Kinnunen et al., 2019). That is why European leaders believe that this must be supported. At the extraordinary meeting of the European Council in Brussels on 1-2 October 2020, EU leaders discussed the digital transformation that will take place in Europe. Digitization is a key pillar of the EU's recovery after the COVID-19 crisis (Androniceanu, 2020a; Platt, 2020). It has a key role to play in promoting new forms of growth and strengthening the EU's resilience. Digital technologies are not only changing the way people communicate, but also, more generally, the way they live and work. The situation created by the COVID-19 pandemic has given the EU a new impetus to work to accelerate the technological transition.

The hypothesis from which we start in this research is that digitalization significantly influences economic growth in every European country. That is why we intend to show in this paper what this influence consists of. What impact digitalization has on economic growth in European states (Kosach et al., 2020). Therefore, the research question we start from is: How does digitalization influence economic growth in European countries? From these research perspectives, we analyse digitalization and economic growth in European states using the main component analysis developed by Hotelling (1936) later on.

\section{Literature review}

Over time, several definitions of digitalization have been proposed. Scott Brennen and Daniel Kriess (2014) define digitalization through digital communication and the impact of digital media on contemporary social life. Digitalization means to integrate digital technologies in business and to produce added economic value. From another perspective, digitalization means to develop business in a digital environment. It creates the digital form of different things.

Digitization means transforming interactions, communications, business functions, and business models into (more) digital data, which is often reduced to a combination of digital and physical, such as Omni channel customer service, integrated marketing, or the industrialization of production with a mix of autonomy, semi-autonomous and manual operations, electronic services and so on. Digitalization also means that the workforce works differently. The human resources are working by using a large variety of digital tools (Mircica, 2020). The digital systems allow them to work in a different way, more "digital" - common, unitary, remote (Ionescu, 2020).

Digital transformation requires cultural change, because digitalization is more about human resources than digital technology. The transformation process involves and requires 
customer-centred organizational changes, supported by management, driven by radical challenges in the culture of organizations and the exploitation of technologies that enable and transform the way employees work (Costea, 2020). Digitalization is the process of converting analogue information into a digital format. In a broader context, digitalization is defined as the social transformation determined by the massive adoption of digital technologies to generate, process and trade information. Digitization determines the creation of common platforms for the development of applications, e-government services, e-commerce, social networks, as well as the availability of online information. Digitalization is difficult to define because it is a term with many variables. Digitization involves the integration of technology in all sectors of a business and results in fundamental changes in the way it operates and in the value it offers to the final consumer (Androniceanu et al., 2020). For every business, digitalization can mean something different, depending on their specificity. For example, in the banking system, digitalization involves both the transposition of data into the virtual environment and the availability to the customer. In contrast, in retail, digitalization means the existence of a virtual sales space. Nations constantly support and take efforts to establish congenial policies towards their sustainability and economic growth (Dvorský et al., 2020a). One of the most important goals of digital transformation is economic growth. Due to digitization, economic growth is achieved, and the competitiveness of goods and services increases (Shpak et al., 2020).

Economic growth is a positive variation in the production of goods and services in an economy (Dvorský et al., 2020b). Many authors examine the influence of selected factors on economic growth. For example, the effect of leaders (Smith, 2020), the legal environment (Virglerova et al., 2020), the socio-cultural changes (Uslu et al., 2020) or the management style (Belas et al., 2020), and so on. The main indicator to measure economic growth is GDP, which we also included in our research. Measuring economic growth is done by calculating GDP growth rates. According to the way of involvement in the economic growth process, there are: (1) direct factors, which include the human factor (labour resources), the material factor (material resources and accumulated production equipment) and the informational-technological factor; (2) indirect factors: the rate of research-development investments, the financial-monetary, the budgetary and fiscal policy of the state, the absorption capacity of the internal market, the ecological policy, the international exchanges, etc (Meyer et al., 2017; Stverkova et al., 2018).

In our research we followed the influence of these factors in relation to digitalization and economic growth. In the literature, special attention is paid to economic growth, because the general well-being of society depends on its level. It is expected that these two concepts of digitization and economic growth will create a new digital economy model. The digital economy is considered to be the fourth industrial revolution, characterized by the ability to transform economies, jobs and even society as a whole, by introducing new technologies and processes (Fila et al., 2020; Ślusarczyk and Ul Haque, 2019; Shpak et al., 2019).The digitalization of economies will help increase access to education, jobs and finance, even if, in the short term, it could lead to a reduction in repetitive and no value-added jobs in almost all economic sectors, whether we are talking about industry, agriculture or services (Androniceanu, 2020b).

From this perspective, in our paper we approached digitalization and economic growth and analyzed the main factors that influence digitalization, economic growth and development through a set of specific variables. The methodology, the main results and discussion are presented in the following sections of our paper. 


\section{Methodology}

Canonical Correlation Analysis (CCA) introduced by Hotelling (Hotelling, 1936) is a statistical technique used to detect the associations between two sets of variables in a dependent relation. The pairs of canonical variates explain the inter- and intra-set variability. The first canonical correlation has the highest importance. The correlation coefficients are significant when their absolute values are greater than 0.45 .

CCA was applied to the set of 27 European state members for 2019 and for 8 indicators

PICBE |

in line with previous research (Georgescu and Kinnunen, 2021). In Table 1, the digitalization indicators (V1-V4) are the independent set and the economic growth indicators (V5-V8) are the dependent set.

Table 1. The main research variables

\begin{tabular}{ccc}
\hline Variable & Variable Label & Source \\
\hline V1 & Digital skills & World Bank \\
V2 & Mobile subscriptions & World Bank \\
V3 & Enterprises with e-commerce & Eurostat \\
V4 & Enterprises with data analysis & Eurostat \\
V5 & Real GDP growth (3yrs avg) & Eurostat \\
V6 & Unit labour cost growth (3yrs avg) & Eurostat \\
V7 & Resource productivity (3yrs avg) & Eurostat \\
V8 & R\&D expenditure of GDP (3yrs avg) & Eurostat \\
\hline
\end{tabular}

Source: Our selection based on Eurostat and World Bank databases.

The goal of CCA is to predict four variables: Real GDP growth (3 years average), Unit labour cost growth ( 3 years average), Resource productivity ( 3 years average), and $R \& D$ expenditure of GDP (3 years average) based on four independent variables: Digital skills, Mobile subscriptions, Enterprises with e-commerce, and Enterprises with data analysis. We used the data collected from Eurostat and World Bank for the years 2018-2019. Figure 1 describes the distributions of digitalization indicators and their correlation. The statistically significant withincorrelations include 0.58 between Enterprises with e-commerce (V3) and Enterprises with data analysis (V4), 0.56 between Digital skills (V1) and the data-analysis activity (V4), and 0.45 between Digital skills (V1) and the e-commerce active (V3).

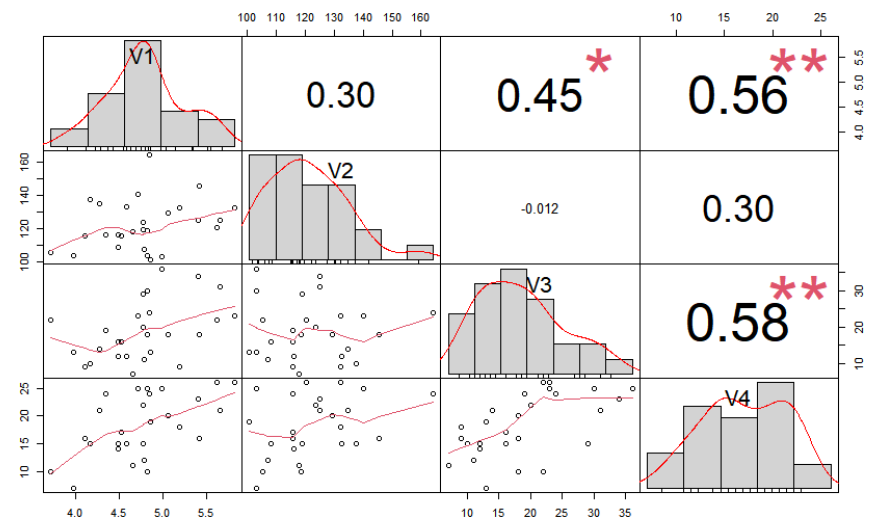

Figure 1. Set 1: Digitalization variables

Source: Authors' own research.

DOI: 10.2478/picbe-2021-0006, pp. 44-57, ISSN 2558-9652 |

Proceedings of the $15^{\text {th }}$ International Conference on Business Excellence 2021 
Figure 2 describes the distributions of economic growth indicators from set 2 and the correlations within set 2 . The statistically significant within-correlations range from negative -0.56 - -0.44 between the real GDP growth (V5) versus R\&D expenditures as a share of GDP (V8) and resource productivity (V7) and from $-0.45--0.43$ between Unit labour cost growth (V6) versus resource productivity (V7) and the growth in unit labour costs (V6); positively statistically significant correlations 0.36-0.37 were detected between real GDP growth (V5) and the growth in unit labour costs (V6) and between Resource productivity (V7) and R\&D expenditure of as a share of GDP (V8), respectively.

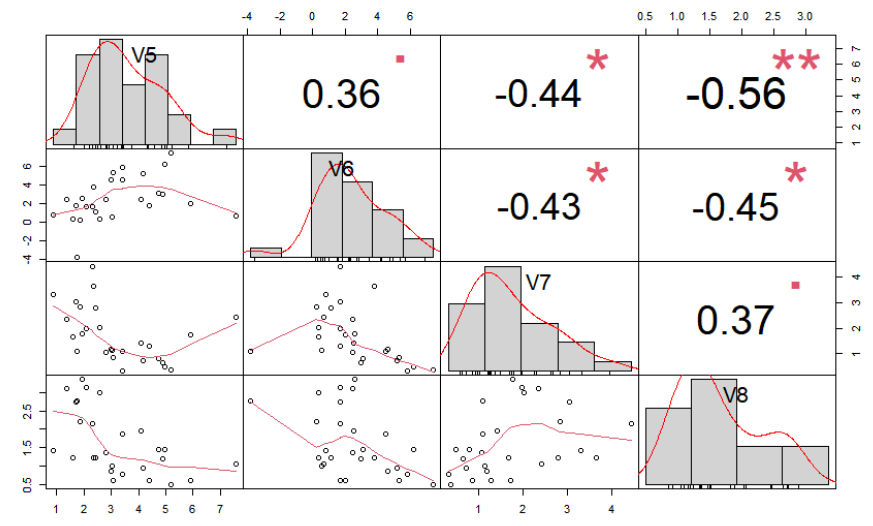

Figure 2. Set 2: Economic growth indicators

The independent set of indicators is denoted by $X=\left(V_{1}, \ldots, V_{4}\right)^{T}$ and the dependent set $Y=\left(V_{5}, \ldots, V_{8}\right)^{T}$. There are four pairs of canonical variates in the model. $A_{i}$ is a linear combination of the elements of set $X$ and $B_{i}$ is a linear combination of elements of set $Y$ :

\begin{tabular}{|l|l|}
\hline$A_{1}=a_{11} V_{1}+\ldots+a_{14} V_{4}$ \\
$\ldots$ \\
$A_{4}=a_{41} V_{1}+\ldots+a_{44} V_{4}$ \\
$B_{1}=b_{11} V_{5}+\ldots+b_{14} V_{8}$ \\
$\ldots$ \\
$B_{4}=b_{41} V_{5}+\ldots+b_{44} V_{8}$ \\
\hline
\end{tabular}

The canonical correlation for the $i^{- \text {th }}$ canonical pair $\left(A_{i}, B_{i}\right)$ is $\rho_{i}^{*}=\frac{\operatorname{cov}\left(A_{i}, B_{i}\right)}{\sqrt{\operatorname{var}\left(A_{i}\right) \operatorname{var}\left(B_{i}\right)}}$, $i=1, \ldots, 4$. By means of CCA we will determine the linear combination that maximizes the canonical correlation $\rho_{i}^{*}$ for the canonical pairs $\left(A_{i}, B_{i}\right), i=1, \ldots, 4$.

First, we find out whether there is any relationship between the two sets $X$ and $Y$. We build a multivariate multiple regression model to predict the economic growth indicators (set $Y$ ) from the digitalization indicators $($ set $X$ ). We have five multiple regression equations. Each of the 
following four multiple regression equations predicts one $Y$ variable from the four variables in set X:

\begin{tabular}{|l|}
\hline$V_{5}=\beta_{10}+\beta_{11} V_{1}+\beta_{12} V_{2}+\beta_{13} V_{3}+\beta_{14} V_{4}$ \\
$\cdots$ \\
$V_{8}=\beta_{40}+\beta_{41} V_{1}+\beta_{42} V_{2}+\beta_{43} V_{3}+\beta_{44} V_{4}$ \\
\hline
\end{tabular}

The null hypothesis that the regression coefficients from above are zero, which is equivalent to testing that the two sets of indicators $\mathrm{X}$ and $\mathrm{Y}$ are independent:

$$
H_{0}: \beta_{i j}=0, i, j=1, \ldots, 4 \text {. }
$$

\section{Results and discussions}

By means of SPSS 26 we analyze the main findings of CCA.

Pillai's trace test, Hotelling's trace test, and Wilk's lambda criteria are significant, with $p$ - values less than 0.05 . The tests in Table 1 prove that there is a statistically significant and positive linear relationship between the dimensions of digitalization and economic growth indicators.

Table 1. Multivariate tests of significance $(S=4, M=-1 / 2, N=81 / 2)$

\begin{tabular}{|l|l|c|c|c|c|}
\hline Test Name & Value & Approx. F & Hypoth. DF & Error DF & Sig. of F \\
\hline Pillais & 1.13306 & 2.17368 & 16 & 88 & 0.011 \\
\hline Hotellings & 2.53494 & 2.77259 & 16 & 70 & 0.002 \\
\hline Wilks & 0.19686 & 2.5759 & 16 & 58.68 & 0.004 \\
\hline Roys & 0.64067 & & & & \\
\hline
\end{tabular}

Source: Authors' own research.

The CCA analysis generated four roots, as seen in Table 2. The eigenvalues are decreasingly ordered.

Table 2. Eigenvalues and canonical correlations

\begin{tabular}{|c|c|c|c|c|c|}
\hline Root No. & Eigenvalue & Pct. & Cum. Pct. & Canon Cor. & Sq. Cor \\
\hline $\mathbf{1}$ & 1.78295 & 70.33496 & 70.33496 & 0.80042 & 0.64067 \\
\hline $\mathbf{2}$ & 0.6376 & 25.15238 & 95.48734 & 0.62398 & 0.38935 \\
\hline $\mathbf{3}$ & 0.11237 & 4.43285 & 99.92019 & 0.31783 & 0.10102 \\
\hline $\mathbf{4}$ & 0.00202 & 0.07981 & 100 & 0.04493 & 0.00202 \\
\hline
\end{tabular}

The eigenvalues are calculated as the ratio between the squared correlation and 1 minus the squared correlation. For instance, the largest eigenvalue 1.78 can be computed as $1.78=$ 0.64

$\overline{1-0.64}$. Canonical correlations are correlation coefficients of the pairs of canonical variates. The first canonical correlation, 0.80042 is the correlation coefficient between the first pair of 
canonical variates. $70.33 \%$ of the variation in $A_{1}$ is explained by the variation in $B_{1}$. This value is the highest in this model, suggesting that the first canonical correlation is the most significant. In Table 3, we test the null hypothesis that all correlations are equal to 0 , equivalent with all pairs of canonical variates are not correlated:

$$
H_{0}: \rho_{1}^{*}=\ldots=\rho_{5}^{*}=0
$$

Since Wilks lambda is significant $(\mathrm{p}=0.004<0.05)$ and the canonical correlations are decreasingly ordered, it follows that $\rho_{1}^{*} \neq 0$. Then, we test the hypothesis that the remaining pairs of canonical variates are correlated:

$$
H_{0}: \rho_{2} *=\ldots=\rho_{5}^{*}=0 .
$$

Since $\mathrm{p}=0.167>0.05$, the second canonical variate pair is not correlated, $\rho_{2}{ }^{*}=0$.

Similarly, the last two tests are not significant, since $p>0.05$.

Table 3. Dimension reduction analysis

\begin{tabular}{|c|c|c|c|c|c|}
\hline Roots & Wilks L. & F & Hypoth. DF & Error DF & Sig. of F \\
\hline 1 TO 4 & 0.19686 & 2.5759 & 16 & 58.68 & 0.004 \\
\hline 2 TO 4 & 0.54786 & 1.52173 & 9 & 48.83 & 0.167 \\
\hline 3 TO 4 & 0.89717 & 0.58544 & 4 & 42 & 0.675 \\
\hline 4 TO 4 & 0.99798 & 0.04451 & 1 & 22 & 0.835 \\
\hline
\end{tabular}

The raw and standardized canonical coefficients for the dependent variables are shown in Tables 4 and 5 .

Table 4. Raw canonical coefficients for dependent variables

\begin{tabular}{|c|c|c|c|c|}
\hline Variable & $\mathbf{1}$ & $\mathbf{2}$ & $\mathbf{3}$ & $\mathbf{4}$ \\
\hline V5 & 0.54546 & -0.01097 & -0.3737 & -0.44885 \\
\hline V6 & -0.07871 & 0.31843 & 0.26747 & -0.27667 \\
\hline V7 & 0.24598 & -0.54037 & 0.59055 & -0.71615 \\
\hline V8 & 1.14658 & 0.82858 & 0.20551 & 0.08423 \\
\hline
\end{tabular}

Source: Authors' own research.

The raw canonical coefficients are interpreted as follows. The canonical variates are interpreted as outcome variables, analogous to linear regression. A one-unit increase in variable V5 Real GDP growth leads to a 0.54546 increase in the first variate of economic growth measurement (Table 4). An increase in one standard deviation in variable V5 (Real GDP growth) leads to a 0.86407 standard deviation increase in the first variate of economic growth measurement (Table 5). 
Table 5. Standardized canonical coefficients for dependent variables

\begin{tabular}{|c|c|c|c|c|}
\hline Variable & $\mathbf{1}$ & $\mathbf{2}$ & $\mathbf{3}$ & $\mathbf{4}$ \\
\hline V5 & 0.86407 & -0.01738 & -0.59198 & -0.71103 \\
\hline V6 & -0.18409 & 0.74478 & 0.62558 & -0.64711 \\
\hline V7 & 0.26365 & -0.57921 & 0.63299 & -0.76761 \\
\hline V8 & 1.01943 & 0.7367 & 0.18272 & 0.07489 \\
\hline
\end{tabular}

Source: Authors' own research.

PICBE |

Using the coefficient values in the second column of Table 4, the first canonical variable for economic growth is:

$$
B_{1}=0.54546 V_{5}-0.07871 V_{6}+0.24598 V_{7}+1.14658 V_{8}
$$

The size of the coefficients shows the contribution of the variables to the canonical variable.

In Table 6, the first canonical variable for economic growth is strongly dominated by V8 R\&D expenditure of GDP, with a correlation coefficient 0.71673 . The second canonical variable for economic growth is positively moderately dominated by V6 Unit labour cost growth with a correlation coefficient 0.66056 , and negatively moderately dominated by V7 Resource productivity (-0.62367). The third canonical variable for economic growth is negatively dominated by V5 Real GDP growth (-0.74752), and by V7 Resource productivity (0.68916). The fourth canonical variable for economic growth is negatively dominated by V5 Real GDP growth $(-0.64767)$ and V6 Unit labour cost growth (-0.60309). Only absolute value correlations above 0.45 are considered significant.

Table 6. Correlations between dependent and canonical variables

\begin{tabular}{|c|c|c|c|c|}
\hline Variable & $\mathbf{1}$ & $\mathbf{2}$ & $\mathbf{3}$ & $\mathbf{4}$ \\
\hline V5 & 0.1141 & 0.09335 & -0.74752 & -0.64767 \\
\hline V6 & -0.44341 & 0.66056 & 0.05777 & -0.60309 \\
\hline V7 & 0.33803 & -0.62367 & 0.68916 & -0.14774 \\
\hline V8 & 0.71673 & 0.20146 & 0.46579 & 0.47827 \\
\hline
\end{tabular}

Source: Authors' own research.

In Table 7, 20.94\% of the variance among the dependent set economic growth is explained by the first dependent canonical variate, while $13.415 \%$ is explained by the first covariate canonical variate. Similarly, $21.865 \%$ of the variance among economic growth is explained by the second dependent canonical variate, while $8.513 \%$ is explained by the second covariate canonical variable. The third dependent canonical variate explains most of the variance among economic growth, $31.35 \%$. 
Table 7. Variance in dependent variables explained by canonical variables

\begin{tabular}{|c|c|c|c|c|}
\hline CAN. VAR. & Pet Var DEP & Cum Pct DEP & Pet Var COV & Cum Pct COV \\
\hline $\mathbf{1}$ & 20.94002 & 20.94002 & 13.41562 & 13.41562 \\
\hline $\mathbf{2}$ & 21.86516 & 42.80518 & 8.51319 & 21.92881 \\
\hline $\mathbf{3}$ & 31.35066 & 74.15584 & 3.167 & 25.09581 \\
\hline $\mathbf{4}$ & 25.84416 & 100 & 0.05218 & 25.14799 \\
\hline
\end{tabular}

PICBE |

Next, we determine the raw and standardized canonical coefficients for the covariates (Tables 8 and 9). A one-unit increase in variable V1 (Digital skills) leads to a 0.61405 increase in the first variate of digitalization (Table 8). An increase of one standard deviation in variable V1 (Digital skills) leads to a 0.32048 standard deviation increase in the first variate of digitalization (Table 9). The first canonical variable for digitalization is expressed as:

$$
A_{1}=0.61405 V_{1}-0.01257 V_{2}+0.09374 V_{8}+0.01778 V_{4}
$$

Table 8. Raw canonical coefficients for covariates

\begin{tabular}{|c|c|c|c|c|}
\hline Covariate & $\mathbf{1}$ & $\mathbf{2}$ & $\mathbf{3}$ & $\mathbf{4}$ \\
\hline V1 & 0.61405 & 1.15521 & 1.78175 & 0.93814 \\
\hline V2 & -0.01257 & 0.03865 & -0.00993 & -0.06111 \\
\hline V3 & 0.09374 & 0.06234 & -0.1157 & -0.01583 \\
\hline V4 & 0.01778 & -0.22833 & 0.07184 & -0.07351 \\
\hline
\end{tabular}

Source: Authors' own research.

Table 9. Standardized canonical coefficients for covariates

\begin{tabular}{|c|c|c|c|c|}
\hline Covariate & $\mathbf{1}$ & $\mathbf{2}$ & $\mathbf{3}$ & $\mathbf{4}$ \\
\hline V1 & 0.32048 & 0.60292 & 0.92992 & 0.48963 \\
\hline V2 & -0.18799 & 0.57783 & -0.14854 & -0.91373 \\
\hline V3 & 0.7489 & 0.49802 & -0.92433 & -0.12649 \\
\hline V4 & 0.09893 & -1.27022 & 0.39968 & -0.40895 \\
\hline
\end{tabular}

Source: Authors' own research.

The correlations from Table 10 show the relative contribution of each covariate to each canonical variable.

Table 10. Correlations between covariates and canonical variables

\begin{tabular}{|c|c|c|c|c|}
\hline Covariate & $\mathbf{1}$ & $\mathbf{2}$ & $\mathbf{3}$ & $\mathbf{4}$ \\
\hline V1 & 0.6543 & 0.29036 & 0.69533 & -0.06403 \\
\hline V2 & -0.07226 & 0.36312 & 0.25917 & -0.89205 \\
\hline V3 & 0.95121 & 0.02934 & -0.27731 & -0.13206 \\
\hline V4 & 0.65063 & -0.47275 & 0.33921 & -0.48797 \\
\hline
\end{tabular}

Source: Authors' own research.

The first canonical variable for digitalization (Table 10) is strongly dominated by V3 (Enterprises with e-commerce) with a correlation coefficient 0.95121 . The fourth canonical variable for digitalization is strongly negatively dominated by V2 (Mobile subscriptions) with 0.89205 . Only absolute correlation values above 0.45 are considered significant. 
In Table 11, $28.21 \%$ of the variance among the covariate set digitalization is explained by the first dependent canonical variate, while $44.03 \%$ of the variance is explained by the first covariate canonical variate.

Table 11. Variance in covariates explained by canonical variables

\begin{tabular}{|c|c|c|c|c|}
\hline CAN. VAR. & Pct Var DEP & Cum Pct DEP & Pct Var COV & Cum Pct COV \\
\hline $\mathbf{1}$ & 28.21275 & 28.21275 & 44.0364 & 44.0364 \\
\hline $\mathbf{2}$ & 4.2879 & 32.50065 & 11.01298 & 55.04937 \\
\hline $\mathbf{3}$ & 1.87544 & 34.37609 & 18.56533 & 73.6147 \\
\hline $\mathbf{4}$ & 0.05327 & 34.42936 & 26.3853 & 100 \\
\hline
\end{tabular}

PICBE |

Similarly, $4.28 \%$ of the variance among digitalization is explained by the second dependent canonical variate, while $11.01 \%$ is explained by the second covariate canonical variate.

In Table 12 are shown regression analysis results of the effect of the digitalization indicators on each economic growth indicator. The importance of each covariate is measured by the values of beta.

Table 12. Regression analysis for cells error term

\begin{tabular}{|c|c|c|c|c|c|c|c|c|}
\hline Covariate & B & Beta & Std. Err. & t-Value & Sig. of t & Lower -95\% & CL-Upper \\
\hline Dependent variable: Real GDP growth (V5) \\
\hline V1 & -0.518406 & -0.170797 & 0.78252 & -0.66249 & 0.515 & -2.14124 & 1.10443 \\
\hline V2 & 0.008304 & 0.078373 & 0.02413 & 0.34406 & 0.734 & -0.04175 & 0.05835 \\
\hline V3 & 0.063589 & 0.320692 & 0.05286 & 1.20302 & 0.242 & -0.04603 & 0.17321 \\
\hline V4 & -0.042147 & -0.148015 & 0.0818 & -0.51523 & 0.612 & -0.2118 & 0.1275 \\
\hline Dependent variable: Unit Labour cost growth (V6) & & \\
\hline V1 & 0.620998 & 0.138571 & 1.00405 & 0.6185 & 0.543 & -1.46126 & 2.70326 \\
\hline V2 & 0.05114 & 0.32692 & 0.03097 & 1.65147 & 0.113 & -0.01308 & 0.11536 \\
\hline V3 & -0.021684 & -0.074067 & 0.06782 & -0.31972 & 0.752 & -0.16234 & 0.11897 \\
\hline V4 & -0.227133 & -0.540244 & 0.10496 & -2.16399 & 0.042 & -0.44481 & -0.00946 \\
\hline Dependent variable: Resource productivity (V7) \\
\hline V1 & 0.107856 & 0.052517 & 0.468 & 0.23046 & 0.82 & -0.86272 & 1.07843 \\
\hline V2 & -0.021664 & -0.302202 & 0.01443 & -1.50095 & 0.148 & -0.0516 & 0.00827 \\
\hline V3 & -0.025868 & -0.192804 & 0.03161 & -0.81829 & 0.422 & -0.09143 & 0.03969 \\
\hline V4 & 0.11779 & 0.611347 & 0.04892 & 2.40763 & 0.025 & 0.01633 & 0.21925 \\
\hline Dependent variable: R\&D expenditure of GDP $($ V8) & & & \\
\hline V1 & 0.694778 & 0.407838 & 0.36207 & 1.91891 & 0.068 & -0.05611 & 1.44566 \\
\hline V2 & -0.004569 & -0.076837 & 0.01117 & -0.40917 & 0.686 & -0.02773 & 0.01859 \\
\hline V3 & 0.03925 & 0.352676 & 0.02446 & 1.60484 & 0.123 & -0.01147 & 0.08997 \\
\hline V4 & -0.008397 & -0.052539 & 0.03785 & -0.22184 & 0.826 & -0.08689 & 0.0701 \\
\hline
\end{tabular}

Source: Authors' own research. 
Based on the results above, we reach the following conclusions:

- The effect of V3 (Enterprises with e-commerce) is more important in absolute value than the effect of V1 (Digital skills) when predicting V5 (Real GDP growth);

- The effect of V4 (Enterprises with data analysis) is more important in absolute value than the effect of V2 (Mobile subscriptions) when predicting V6 (Unit labour cost growth);

- The effect of V4 (Enterprises with data analysis) is more important in absolute value than the effect of V2 (Mobile subscriptions) when predicting V7 (Resource productivity);

PICBE |

- The effect of V1 (Digital skills) is more important in absolute value than the effect of V3 (Enterprises with e-commerce) when predicting V8 (R\&D expenditure of GDP).

\section{Conclusion}

The connections between economic growth and the level of digitalization were under investigation by canonical correlation analysis, CCA. Figure 3 summarizes the key findings: the first root obtained by CCA explained $70.33 \%$ of the variation between the two phenomena with the correlation of 0.800 . The (explanatory) set of digitalization explained $28.21 \%$ of the first canonical variate, while the canonical explained $20.94 \%$ of the (dependent) set of economic growth. The individual variables correlations with the canonical variates were positive except for the unit labour cost growth (and close-to-zero for mobile subscriptions).

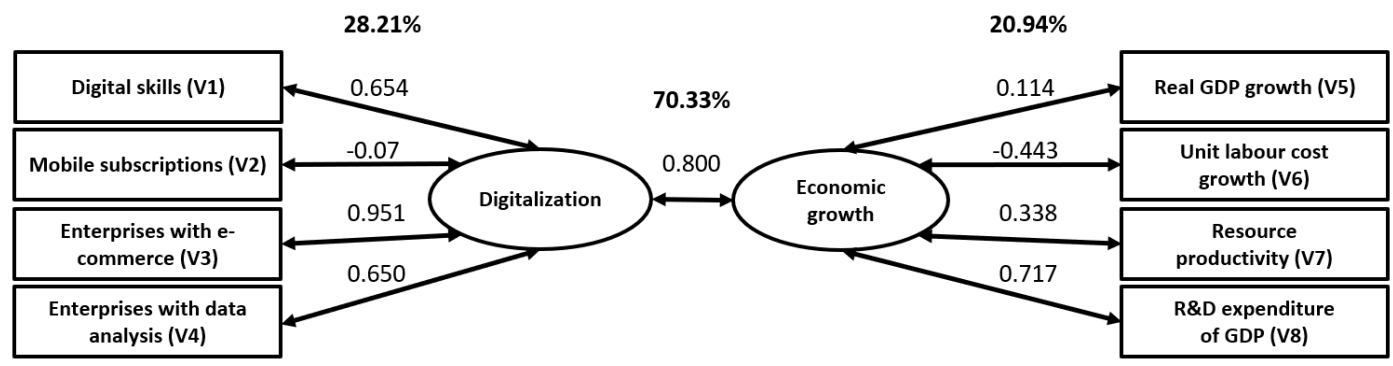

Figure 3. Summary of canonical correlations

Source: Authors' own research.

The regression analysis showed that real GDP growth was mainly dependent on the share of enterprises involved with e-commerce (V3), unit labour costs and resource productivity were mostly affected by enterprises conducting data analysis on customers for marketing purposes (V4), and higher digital skills meant also larger R\&D expenditures as a share of GDP.

We note that a short three-year period under analysis limits the generalization of our results and, while applicable to the EU-27 countries, the other digitally developed economic areas, and even more so for less developed, different dependencies may be found. For future research, an extension to time-series analysis is suggested.

\section{References}

Androniceanu, A., Georgescu, I., \& Kinnunen, J. (2019). Digitalization clusters within the European Union. In K. S. Soliman, K.S. (Ed.). Proceedings of the 33rd International Business Information Management Association Conference (IBIMA): Education Excellence and Innovation Management through Vision 2020 (pp. 1719-1729). April 10-11, 2019, Granada, Spain. 
Androniceanu, A.-M., Kinnunen, J., Georgescu, I., \& Androniceanu, A. (2020a). A multidimensional approach to competitiveness, innovation and well-being in the EU using Canonical Correlation Analysis. Journal of Competitiveness, 12(4), 5-21. https://doi.org/10.7441/joc.2020.04.01.

Androniceanu, A.-M., Georgescu, I., Tvaronavičiene, M., \& Androniceanu, A. (2020b). Canonical correlation analysis and a new composite index on digitalization and labor force in the context of the Industrial Revolution 4.0. Sustainability, 12(17), Article number: 6812; https://doi.org/10.3390/su12176812; https://www.mdpi.com/2071-1050/ $12 / 17 / 6812$.

Androniceanu, A., Georgescu, I., Kinnunen, J., \& Androniceanu, A.-M. (2020a) Multidimensional analysis of consumer behaviour on the European digital market. In Sroka W. (Ed.). Perspectives on Consumer Behaviour. Theoretical Aspects and Practical Applications (pp. 75-95), Cham: Springer. DOI: 10.1007/978-3-030-47380-8.

Androniceanu, A. (2020a). Major structural changes in the EU policies due to the problems and risks caused by COVID-19. Administratie si Management Public, 34, 137-149. DOI: 10.24818/amp/2020.34-08.

Androniceanu A. (2020b). Innovative digital models for an intelligent and sustainable education. In: Peters M., Heraud R. (eds) Encyclopedia of Educational Innovation. Singapore: Springer. DOI: https://doi.org/10.1007/978-981-13-2262-4.

Belas, J., Amoah, J., Petráková, Z., Kliuchnikava, Y., \& Bilan, Y. (2020). Selected Factors of SMEs Management in the Service Sector. Journal of Tourism and Services, 21(11), 129-146. DOI: 10.29036/jots.v11i21.215.

Bimber, B., Flanagin, A.J., \& Stohl, C. (2012). Collective action in organizations: interaction and engagement in an era of technological change. New York: Cambridge University Press, 2012. 240p.

Brennen, S., \& Kreiss, D. (2014). Digitalization and Digitization. Retrieved January 23, 2021, from https://culturedigitally.org/2014/09/digitalization-and-digitization/.

Connolly-Barker, M., Kliestik, T., Suler, P., \& Zvarikova, K. (2020). Real-time decision-making in the information technology-driven economy: planning, managing, and operating smart sustainable cities. Geopolitics, History, and International Relations, 12(1), 73-79. doi:10.22381/GHIR12120206.

Costea, E.-A. (2020). Machine earning-based natural language processing algorithms and electronic health records data. Linguistic and Philosophical Investigations, 19, 93-99. doi: 10.22381/LPI1920205.

Dvorský, J., Petráková, Z., \& Fialová, V. (2020a). Perception of Business Risks by Entrepreneurs According to Experience with the Business Failure. International Journal of Entrepreneurial Knowledge, 8(1), 76-88. DOI: 10.37335/ijek.v8i1.104.

Dvorský, J., Petráková, Z., Khan, K.A., Formánek, I., \& Mikoláš, Z. (2020b). Selected Aspects of Strategic Management in the Service Sector. Journal of Tourism and Services, 20(11), 109-123. DOI: 10.29036/jots.v11i20.146.

Fila, M., Levicky, M., Mura, L., Maros, M., \& Korenkova, M. (2020). Innovations for business management: motivation and barriers. Marketing and Management of Innovations, 4, 266-278. http://doi.org/10.21272/mmi.2020.4-22.

Georgescu, I., \& Kinnunen, J. (2021). The digital effectiveness on economic inequality: a computational approach. In Dima A.M., D'Ascenzo F. (Eds.). Business Revolution in a 
Digital Era. Springer Proceedings in Business and Economics. Springer, Cham. https://doi.org/10.1007/978-3-030-59972-0_16.

Hotelling, H. (1936). Relations between two sets of variates. Biometrika, 28, 3-4, 321-377. https://doi.org/10.1093/biomet/28.3-4.321.

Kinnunen, J., Androniceanu, A., \& Georgescu, I. (2019). Digitalization of EU countries: a clusterwise analysis. Proceedings of the International Management Conference: Management Strategies for High Performance. Faculty of Management, Academy of

PICBE | 56

Kinnunen, J., \& Georgescu, I. (2020). Disruptive Pandemic as a Driver towards Digital Coaching in OECD Countries. Revista Romaneasca pentru Educatie Multidimensionala, 12(2Sup1), 55-61. https://doi.org/10.18662/rrem/12.2Sup1/289.

Ključnikov, A., Mura, L., \& Sklenár, D. (2019). Information security management in SMEs: factors of success. Entrepreneurship and Sustainability Issues, 6 (4), 2081-2094. https://doi.org/10 .9770/jesi.2019.6.4(37) ISSN 2345-0282.

Meyer, D.F., Masehla, T.M., \& Kot, S. (2017). The relationship between economic growth and economic development: A regional assessment in South Africa. Journal of Advanced Research in Law and Economics, 8 (4), 1377-1385. DOI: 10.14505/jarle.v8.4(26).38.

Mircica, N. (2020). Restoring public trust in digital platform operations: machine learning algorithmic structuring of social media content. Review of Contemporary Philosophy, 19, 85-91. doi:10.22381/RCP1920209.

Hotelling, H. (1936). Relations between two sets of variables. Biometrika, 28(3/4), 321-377. https://doi.org/10.1093/biomet/28.3-4.321.

Ionescu, L. (2020). Robotic process automation, deep learning, and natural language processing in algorithmic data-driven accounting information systems. Analysis and Metaphysics, 19, 59-65. doi:10.22381/AM1920206.

Kosach, I., Duka, A., Starchenko, G., Myhaylovska, O., \& Zhavoronok, A. (2020). Socioeconomic viability of public management in the context of European integration processes. Administratie si Management Public, 35, 139-152. DOI: 10.24818/amp/ 2020.35-09.

Platt, C. (2020). Emotional and psychological distress related to covid-19 isolation, quarantine, and physical distancing: evidence of gender-based differences. Journal of Research in Gender Studies, 10(2), 63-72. doi:10.22381/JRGS10220202.

Shpak, N., Odrekhivskyi, M., Doroshkevych, K., \& Sroka, W. (2019). Simulation of innovative systems under Industry 4.0 conditions. Social Sciences, 8, 202; doi:10.3390/ socsci8070202.

Shpak, N., Kuzmin, O., Dvulit, Z., Onysenko, T., \& Sroka, W. (2020). Digitalization of the marketing activities of enterprises: case study, Information, 11, 109; DOI: 10.3390/ info11020109.

Ślusarczyk, B., \& Ul Haque, A. (2019). Public services for business environment: challenges for implementing Industry 4.0 in Polish and Canadian logistic enterprises. Administratie si Management Public, 33, 57-76, DOI: 10.24818/amp/2019.33-04.

Smith, M. (2020). Effective Leadership in Online Small Businesses: an Exploratory Case Study. International Journal of Entrepreneurial Knowledge, 8(2), 27-41. DOI: 10.37335/ ijek.v8i2.117. 
Stverkova, H., Pohludka, M., Kurowska-Pysz, J., \& Szczepańska-Woszczyna, K. (2018) Crossborder entrepreneurship in Euroregion Beskydy. Polish Journal of Management Studies, 18 (2), 324-337. DOI: 10.17512/pjms.2018.18.2.26.

Uslu, A., Alagöz, G., \& Güneş, E. (2020). Socio-cultural, Economic, and Environmental Effects of Tourism from the Point of View of the Local Community. Journal of Tourism and Services, 21(11), 1-21. DOI: 10.29036/jots.v11i21.147.

Virglerova, Z., Conte, F., Amoah, J., \& Massaro, M. R. (2020). The Perception of Legal Risk PICBE | and Its Impact on the Business of SMEs. International Journal of Entrepreneurial Knowledge, 8(2), 1-13. DOI: 10.37335/ijek.v8i2.115. 